\title{
Micro-nutrient related malnutrition and obesity in a university undergraduate population and implications for non-communicable diseases
}

\author{
Foluke A Olatona ${ }^{1}$ @ , Sunday A Aderibigbe², Eyitope O Amu ${ }^{3}$, Oluseye O Onabanjo ${ }^{4}$, Kelechi E Nnoaham ${ }^{5}$ \\ 1 Department of Community Health \& Primary Care, College of Medicine, University of Lagos, Lagos State, Nigeria, 2 Department of Epidemiology \& \\ Community Health, Faculty of Clinical Sciences, University of Ilorin, Ilorin, Nigeria, ${ }^{3}$ Department of Community Medicine, College of Medicine, Ekiti \\ State University, Ado-Ekiti, Ekiti State, ${ }^{4}$ Department of Nutrition and Dietetics, College of Food Science and Human Ecology, Federal University of \\ Agriculture, Abeokuta, 5 Faculty of Health \& Human Sciences, Plymouth University, Plymouth, UK \\ Keywords: micronutrient, obesity, malnutrition
}

https://doi.org/10.29392/001c.17603

\section{Journal of Global Health Reports}

Vol. 4, 2020

\section{Background}

Micronutrient deficiency and obesity are increasing globally. This study determined the prevalence of micronutrient-related malnutrition, patterns of obesity using different methods of assessment, and the predictors of obesity among the university undergraduate population in Lagos State, Nigeria.

\begin{abstract}
Methods
A multistage sampling technique was adopted to select 506 students from the three universities in Lagos State. A pre-tested, semi-structured interviewer-administered questionnaire was used to obtain data on socio-demographic and economic characteristics. Nutrient intakes were estimated from 24-hour dietary recalls, obesity was assessed through anthropometric measurements and Bio-electrical Impedance Analysis, following standard procedures. Associations between variables were tested using Chi-square, Fischer's exact tests, and logistic regression analyses. Twenty-four-hour diet recall was analyzed using the Total Diet Assessment soft-ware. Anthropometric indices were compared with World Health Organization (WHO) standards and classified.
\end{abstract}

\section{Results}

Mean daily intake of almost all micronutrients was low except sodium which was in excess compared to the recommended dietary allowances. The prevalence of underweight was $6.6 \%$, overweight (16.4\%), and obesity (3.2\%) based on body mass index (BMI). Abdominal obesity was higher than general obesity. Obesity assessed using the percentage body fat had the highest yield of $54.4 \%$ in males and $37.1 \%$ in females.

\section{Conclusions}

Micronutrient-related malnutrition and central obesity were higher than reported in previous studies. Male gender, inconsistent income, and increased amount of folate were significant predictors of obesity. The students will benefit from nutrition education that emphasize the consumption of micronutrient dense foods and different methods of weight management.

Malnutrition remains a significant problem worldwide, but the types of nutritional problems have changed significantly over the past two decades. While under-nutrition was and is still a major threat to health and well-being in middle-and low-income countries, obesity has equally become an additional problem in such countries with increasing prevalence. Micronutrient disorders are a global problem affecting about 2 billion people in both developing and developed countries. They are quiet epidemics of vitamin and mineral deficiencies that affect people of all genders and ages, as well as certain risk groups. In addition to causing definite disease conditions, they also worsen infectious and chronic diseases, significantly impacting morbidity, mortality, and quality of life. ${ }^{1}$ The nutrition transition in sub-Saharan African countries is complex because over-nutrition associated with overweight, obesity and other non-communicable diseases (NCDS) emerged before the problems of under-nutrition and micronutrient deficiencies have been solved, creating a double burden of nutrition-related ill-health. ${ }^{2-4}$

Obesity has more than doubled since 1980 globally. In 2008, more than 1.4 billion adults 20 years and above were 
overweight. Out of these, an estimated 205 million men and 297 million women, that is more than half a billion adults were obese. ${ }^{5}$ In 2008 , the global prevalence of obesity was $10 \%$ and $14 \%$ among men and women respectively compared with $5 \%$ and $8 \%$ in 1980 . In $2014,39 \%$ of the world's adult population were overweight while $13 \%$ were obese. ${ }^{6}$ According to the report by the World Health Organization (WHO), ${ }^{7}$ over $26.8 \%$ and $6.5 \%$ of adults are overweight and obese respectively in Nigeria. The prevalence of overweight was $26 \%$ and $37 \%$ in men and women respectively, while the prevalence of obesity was $3 \%$ and $8.1 \%$ in men and women respectively. ${ }^{7}$ Among individuals aged 30 years and above, the prevalence of overweight and obesity together increased by $23 \%$ in men and $18 \%$ in women, while that of obesity alone increased by $47 \%$ in men and $39 \%$ in women, between 2002 and 2010, in Nigeria. ${ }^{8}$ In South West Nigeria, 29\% of the University undergraduate students were overweight, $6 \%$ were obese while $13 \%$ were underweight. ${ }^{2}$

The WHO considers that more than 2 billion people worldwide suffer from micronutrient deficiencies, primarily iodine, iron, vitamin A and zinc, with important health consequences. ${ }^{9}$ Though all ages and both sexes are affected, children less than 5 years of age, adolescents, women of childbearing age, particularly the pregnant and lactating, refugees and victims of famine are mostly at risk. ${ }^{10}$ Among university undergraduates in Lagos, Nigeria, only 31\% eat up to three times daily, only $23 \%$ eat breakfast while only $2 \%$ consumed the recommended daily allowance of fruits and vegetables. ${ }^{11}$

Overweight and obesity are associated with many diseases. These include hypertension, diabetes mellitus, atherosclerosis, certain types of cancers, chronic kidney disease and increased overall cardiovascular risk. ${ }^{12-16}$ Others include asthma, osteoarthritis, and low back pain. Each $5 \mathrm{~kg} / \mathrm{m}^{2}$ increase in BMI is associated with a $30 \%$ higher overall mortality risk and higher mortality from stroke, kidney disease, and diabetes mellitus in addition to reduced life expectancy by as much as ten years in those with BMI over $40 \mathrm{~kg} / \mathrm{m}^{2} .12$ The public health implications of micronutrient disorders are also potentially huge. They do not only cause obvious clinical manifestations, but are also responsible for a wide range of non-specific physiological impairments, leading to reduced resistance to infections, metabolic disorders, and delayed or impaired physical and psychomotor development. ${ }^{17}$ In adults, they are also associated with the risk of several chronic diseases including cardiovascular diseases (CVD), osteoporosis and cancer. ${ }^{18}$

Obesity in young people in middle income countries, has serious implications in later $\operatorname{life}^{8}$ due to its consequences. The transition to higher education involves a significant life change (in environment and resources) for many students as they often start living away from their parental home for the first time, get more freedom and make new friends. ${ }^{19,20}$ This period is accompanied with un-favorable changes in health behaviors and has been implicated as a risk period for weight gain. ${ }^{21}$ The rates of obesity have increased rapidly among University students globally and locally and a recent study among undergraduates in Nsukka Campus Nigeria revealed a prevalence as high as $21 \%{ }^{22,23}$

Some studies have explored the prevalence of obesity among undergraduates $8,11,24,25$ but there is limited infor- mation on nutrient intake, the pattern of obesity using different methods of assessment and relationships between micronutrient disorders and obesity among university undergraduate students in Lagos. This study, therefore, determined the nutrient intake, the pattern of obesity using different methods of assessment and relationships between micronutrient disorders and obesity among university undergraduate students in Lagos State. The result will be useful for policymakers in detecting areas where intervention is needed in the prevention of obesity and micronutrient deficiency.

\section{METHODS}

A descriptive cross-sectional design was used to obtain data from full time undergraduate students in the three Universities in Lagos: University of Lagos (UNILAG), Lagos State University (LASU) and Caleb University.

A multistage sampling technique was employed to select the students from the universities. All the three Universities were included. Simple random sampling was used to select four faculties from the twelve in UNILAG and LASU and one college from Caleb. Using simple random sampling technique (balloting), at least one quarter of the number of departments was selected from each faculty making eleven (11) from UNILAG, five (5) from LASU and one from Caleb University.

Using sampling proportional to size, students were selected across faculties, departments and levels depending on the total population of students in each faculty, department and level. Systematic random sampling technique was employed in each class to select respondents. The number required from each class was used to divide the class list to determine the sampling interval. The total number of students interviewed was five hundred and six.

\section{DATA COLLECTION}

Pre-tested, semi-structured interviewer administered questionnaire was used to obtain data on socio demographic and economic characteristics. Mean nutrient intakes were estimated from 24-hour dietary recalls which were conducted on two days of the week (one week day and one week end day). General and abdominal obesity were assessed using anthropometric measurements while percentage body fat was determined using Bio-electrical Impedance Analysis, following standard procedures.

\section{DATA ANALYSIS}

IBM SPSS Statistics (version 20) was used for data analysis. Associations between variables were tested using Chisquare and Fischer's exact tests. Twenty-four (24) hour-diet recall was analyzed using Total Diet Assessment soft-ware. Anthropometric indices were compared with WHO standards and classified. 


\section{RESULTS}

\section{SOCIO-DEMOGRAPHIC STATUS}

Their ages ranged from 15 to 41 years but the modal age group was 19-24 years while the mean age of the respondents was $20.3+3.45$ years. More than half of the respondents (54.7\%) were females and majorities were Christians' (82.9\%). Majority (47.6\%) of the students had no consistent source of income or received less than N10,000 (USD 31.7) pocket money.

\section{MEAN ENERGY AND NUTRIENT INTAKE OF RESPONDENTS}

Mean nutrient intake of respondents were compared with FAO/WHO 2001 standards for daily recommended intakes of nutrients according to sex and age group. Most micro-nutrients were deficient except thiamine, and zinc. Micronutrients such as iron, calcium, potassium, folate, vitamin $\mathrm{C}$, B2, B6 and B12 were inadequate while intake of sodium was higher than the recommended values for some age groups. There was no statistically significant difference between male and female mean nutrient intake for all the nutrients. (Tables $\underline{1}$ and $\underline{2}$ )

\section{OVERALL BMI CLASSIFICATION OF ALL THE RESPONDENTS}

According to Body Mass Index (BMI) classification, most of the students (73.9\%) were in the normal range of BMI. Only few of them were underweight (6.6\%), overweight (16.4\%) and obese (3.2\%) (Figure 1).

\section{PATTERN OF OBESITY USING DIFFERENT ASSESSMENT METHODS BY GENDER}

Body mass index showed that $3 \%$ of males and $3.3 \%$ of females were obese. Based on waist circumference (WC), 1.3\% of males and $8.4 \%$ of females were obese, whereas $12.3 \%$ of males and $26.5 \%$ of females were obese using Waist to Hip ratio (WHR). Prevalence of abdominal (central) obesity was significantly higher among females than males ( $P=0.000$ for both WC and WHR). Obesity assessed using the percentage body fat had the highest yield of $54.4 \%$ in males and $37.1 \%$ in females. The difference between males and females were not statistically significant $(P=0.69)$ (Table 3).
Nutritional Status of the undergraduate students

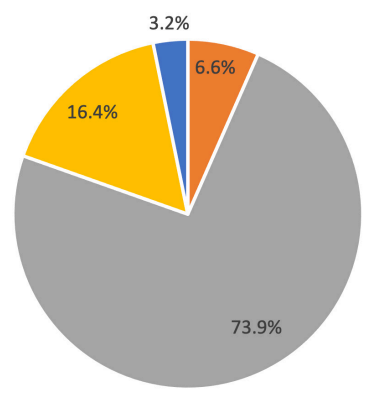

- = Underweight $\mid$ Normal BMI $=$ Overweight - Obese

Figure 1. Body Mass Index (BMI) classification of all the respondents 
Table 1. Respondents' mean energy and mineral intake compared with RDA for sex and age group

\begin{tabular}{|c|c|c|c|c|c|c|c|c|}
\hline & & Male & & & Female & & & \\
\hline Nutrient & $\begin{array}{c}\text { Age } \\
\text { in } \\
\text { years }\end{array}$ & $\begin{array}{l}\text { Mean/ } \\
\text { Median } \\
\text { Intake }\end{array}$ & RDA & $\begin{array}{c}\text { Intake } \\
\text { as } \% \\
\text { of } \\
\text { RDA } \\
\text { (\%) }\end{array}$ & $\begin{array}{l}\text { Mean/Median } \\
\text { Intake }\end{array}$ & RDA & $\begin{array}{c}\text { Intake } \\
\text { as } \% \\
\text { of } \\
\text { RDA }\end{array}$ & $P$-value \\
\hline \multirow[t]{3}{*}{ Energy (Kcal) } & $15-18$ & $\begin{array}{c}1543.8 \pm \\
640.6\end{array}$ & 2800 & $\underline{55.1}$ & $1418.4 \pm 596.6$ & 2000 & $\underline{70.9}$ & 0.202 \\
\hline & $19-30$ & $\begin{array}{c}1550.2 \pm \\
637.7\end{array}$ & 2700 & $\underline{57.4}$ & $1552.7 \pm 625.9$ & 2200 & $\underline{70.6}$ & 0.971 \\
\hline & $31-50$ & $\begin{array}{c}1452.8 \pm \\
347.8\end{array}$ & 2600 & $\underline{55.9}$ & $1249.7 \pm 496.5$ & 2000 & $\underline{62.5}$ & 0.465 \\
\hline \multirow[t]{3}{*}{ Protein(g) } & $15-18$ & $49.2 \pm 26.8$ & 52 & 94.6 & $45.8 \pm 21.9$ & 46 & 99.6 & 0.379 \\
\hline & $19-30$ & $49.3 \pm 29.6$ & 56 & 88.0 & $48.4 \pm 22.8$ & 46 & 105.2 & 0.755 \\
\hline & $31-50$ & $54.3 \pm 16.1$ & 56 & 97.0 & $39.5 \pm 19.0$ & 46 & 85.9 & 0.220 \\
\hline \multirow[t]{3}{*}{ Carbohydrate(g) } & $15-18$ & $238.5 \pm 101.1$ & 130 & $\underline{183.8}$ & $220.1 \pm 87.7$ & 130 & 169.2 & 0.219 \\
\hline & $19-30$ & $244.3 \pm 98.8$ & 130 & 187.9 & $244.0 \pm 100.6$ & 130 & 187.7 & 0.978 \\
\hline & $31-50$ & $225.9 \pm 44.1$ & 130 & 173.7 & $205.1 \pm 61.7$ & 130 & 157.7 & 0.548 \\
\hline \multirow[t]{3}{*}{ Fibre (g) } & $15-18$ & $8.1 \pm 5.1$ & 38 & $\underline{21.3}$ & $8.0 \pm 5.0$ & 26 & $\underline{30.8}$ & 0.901 \\
\hline & $19-30$ & $8.1 \pm 5.1$ & 38 & $\underline{22.9}$ & $9.3 \pm 7.2$ & 25 & $\underline{37.2}$ & 0.089 \\
\hline & $31-50$ & $4.6 \pm 2.7$ & 38 & $\underline{16.8}$ & $9.2 \pm 9.1$ & 25 & $\underline{36.8}$ & 0.267 \\
\hline \multirow[t]{3}{*}{ Fat(g) } & $15-18$ & $42.9 \pm 28.3$ & 90 & 47.7 & $37.3 \pm 26.2$ & 70 & 53.1 & 0.196 \\
\hline & $19-30$ & $39.7 \pm 26.1$ & 71 & 55.9 & $40.8 \pm 26.4$ & 56 & 72.9 & 0.705 \\
\hline & $31-50$ & $33.8 \pm 22.1$ & 69 & 49.0 & $27.7 \pm 22.0$ & 57 & 48.6 & 0.680 \\
\hline \multirow[t]{3}{*}{ Calcium(mg) } & $15-18$ & $\begin{array}{c}327.9 \pm \\
225.2\end{array}$ & 1100 & $\underline{29.8}$ & $314.9 \pm 195.2$ & 1300 & $\underline{24.2}$ & 0.716 \\
\hline & $19-30$ & $358.4 \pm 324.3$ & 1000 & $\underline{35.8}$ & $334.9 \pm 198.7$ & 1000 & $\underline{33.5}$ & 0.417 \\
\hline & $31-50$ & $\begin{array}{c}400.6 \pm \\
380.7\end{array}$ & 1000 & $\underline{37.8}$ & $345.3 \pm 192.3$ & 1000 & $\underline{34.5}$ & 0.798 \\
\hline \multirow[t]{3}{*}{ Sodium(mg) } & $15-18$ & $\begin{array}{c}967.4 \\
(1257.5)\end{array}$ & 1500 & 64.5 & $1279.6(1473.6)$ & 1500 & 85.3 & 0.154 \\
\hline & $19-30$ & $\begin{array}{c}1397.7 \\
(1227.8)\end{array}$ & 1500 & 93.2 & 1378.9(1431.7) & 1500 & 91.9 & 0.659 \\
\hline & $31-50$ & $885.4 \pm 770$ & 1500 & $\underline{395.5}$ & $1959.7 \pm 1455$ & 1500 & 130.6 & 0.162 \\
\hline \multirow[t]{3}{*}{ Potassium(mg) } & $15-18$ & $\begin{array}{c}991.3 \pm \\
588.5\end{array}$ & 4700 & $\underline{21.1}$ & $973.7 \pm 585.3$ & 4700 & $\underline{20.7}$ & 0.850 \\
\hline & $19-30$ & $\begin{array}{c}839.1 \\
(790.3)\end{array}$ & 4700 & $\underline{17.9}$ & 777.7 (658.4) & 4700 & $\underline{16.6}$ & 0.377 \\
\hline & $31-50$ & $\begin{array}{c}665.0 \pm \\
433.7\end{array}$ & 4700 & 14.1 & $618.3 \pm 315.5$ & 4700 & $\underline{13.1}$ & 0.859 \\
\hline \multirow[t]{3}{*}{ Zinc(mg) } & $15-18$ & $7.1 \pm 4.56$ & 9.7 & 73.2 & $7.6 \pm 4.65$ & 7.8 & 97.3 & 0.521 \\
\hline & $19-30$ & $6.47(6.41)$ & 7 & 107.1 & $6.3(5.09)$ & 4.9 & 159.2 & 0.999 \\
\hline & $31-50$ & $8.2 \pm 2.64$ & 7 & 117.1 & $6.3 \pm 1.75$ & 4.9 & 128.6 & 0.248 \\
\hline \multirow[t]{3}{*}{ Iron(mg) } & $15-18$ & $\begin{array}{c}14.12 \pm \\
11.68\end{array}$ & 19 & $\underline{74.7}$ & $14.27 \pm 9.75$ & 31 & $\underline{46.1}$ & 0.930 \\
\hline & $19-30$ & $\begin{array}{c}15.55 \pm \\
10.42\end{array}$ & 14 & 109.3 & $15.12 \pm 9.65$ & 29 & $\underline{51.7}$ & 0.697 \\
\hline & $31-50$ & $13.29 \pm 2.37$ & 14 & 92.9 & $12.52 \pm 2.34$ & 29 & 44.8 & 0.627 \\
\hline
\end{tabular}


Table 2. Respondents' mean vitamin intake compared with RDA for sex and age group

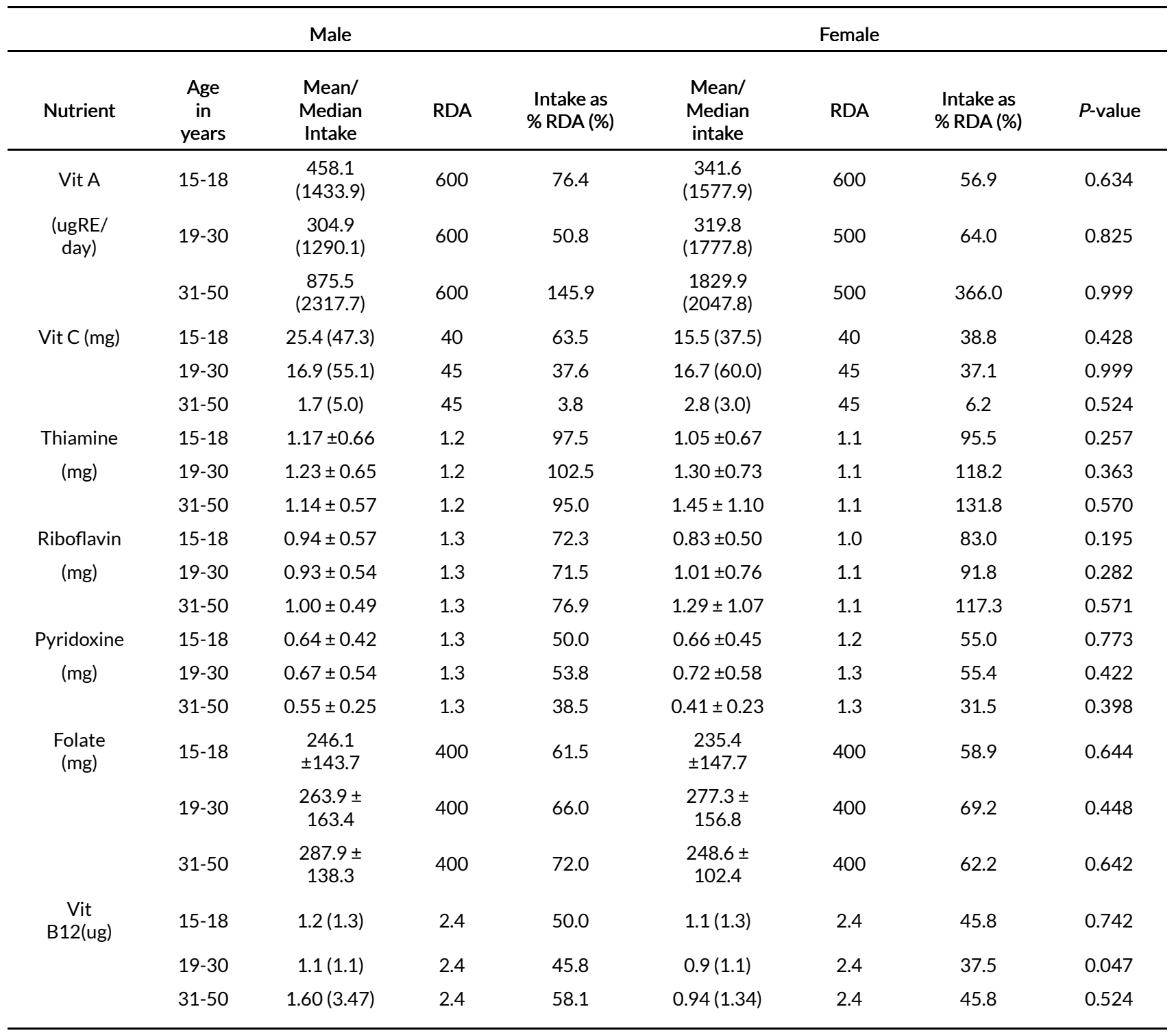

RDA - Recommended Daily Allowance, Vit - Vitamin 
Table 3. Pattern of obesity using different assessment methods by gender

\begin{tabular}{|c|c|c|c|c|c|c|c|c|c|c|}
\hline & Male $(\mathrm{N}=228$ & & & Female $(\mathrm{N}=$ & & & Total & & $x^{2}$ & $P$-value \\
\hline Measures of obesity & Normal (\%) & Overweight (\%) & Obesity (\%) & Normal (\%) & Overweight (\%) & Obesity (\%) & Overweight (\%) & Obesity (\%) & & \\
\hline BMI & 168 (73.7) & $38(16.7)$ & $6(3.0)$ & $202(74)$ & $44(16.1)$ & $79(3.3)$ & $82(16.4)$ & $85(3.2)$ & 0.008 & 0.996 \\
\hline WC & $215(94.3)$ & $10(4.4)$ & $3(1.3)$ & $188(68.4)$ & $64(23.3)$ & $23(8.4)$ & $74(15)$ & $26(5)$ & 49.458 & 0.000 \\
\hline WHR & $200(87.7)$ & & $28(12.3)$ & $187(68)$ & & $73(26.5)$ & & $100(20)$ & 15.123 & 0.000 \\
\hline Percentage body fat & $104(45.6)$ & & $124(54.4)$ & $173(62.9)$ & & $102(37.1)$ & & $226(45 \%)$ & 266.8 & 0.69 \\
\hline
\end{tabular}

BMI: Underweight $<18.5 \mathrm{~kg} / \mathrm{m}^{2}$, normal:18.5-24.99kg/ $/ \mathrm{m}^{2}$, overweight: $25-29.99 \mathrm{~kg} / \mathrm{m}^{2} \&$ obese $>30 \mathrm{~kg} / \mathrm{m}^{2}$.

Waist Circumference (WC): Overweight: > $>4 \mathrm{~cm}(\mathrm{M}) ;>>0 \mathrm{~cm}(\mathrm{~F})$, Obesity: $>102 \mathrm{~cm}(\mathrm{M}) ;>88 \mathrm{~cm}(\mathrm{~F})$.

Waist to Hip Ratio (WHR): Obesity $\geqslant 0.90 \mathrm{~cm}(\mathrm{M})$ ) $\geqslant 0.85 \mathrm{~cm}$ (F); Percentage body fat: $>25 \%$ in males; >30\% in females 
Table 4. Prevalence of micro-nutrient-deficient diet or excess among the undergraduates

\begin{tabular}{|c|c|c|c|c|c|}
\hline \multirow[b]{2}{*}{ Micro-nutrient } & \multicolumn{2}{|c|}{ Males $(\mathrm{N}=228)$} & \multicolumn{2}{|c|}{ Females (N=275) } & \multirow[b]{2}{*}{$P$-value } \\
\hline & $\begin{array}{l}\text { RDA } \\
(\mathrm{Mg})\end{array}$ & $\begin{array}{l}\text { Deficient/ excess micro- } \\
\text { nutrients (\%) }\end{array}$ & $\begin{array}{l}\text { RDA } \\
(\mathrm{Mg})\end{array}$ & $\begin{array}{l}\text { Deficient/ excess micro- } \\
\text { nutrients (\%) }\end{array}$ & \\
\hline Calcium deficiency & 1100 & $225(98.7)$ & 1200 & $274(99.6)$ & 0.23 \\
\hline Iron deficiency & 14 & $140(61.4)$ & 29 & $162(58.9)$ & 0.570 \\
\hline Zinc deficiency & 7 & $128(56.1)$ & 4.9 & $152(55.3)$ & 0.916 \\
\hline Folate deficiency & 400 & $191(83.8)$ & 400 & $231(84)$ & 0.958 \\
\hline $\begin{array}{l}\text { Potassium } \\
\text { deficiency }\end{array}$ & 4700 & $228(100)$ & 4700 & $274(99.6)$ & 0.100 \\
\hline Excess sodium & 1500 & $97(43.0)$ & 1500 & $105(38.0)$ & 0.367 \\
\hline $\begin{array}{l}\text { Pyridoxine } \\
\text { deficiency }\end{array}$ & 1.3 & $211(92.5)$ & 1.3 & $248(90.2)$ & 0.351 \\
\hline $\begin{array}{l}\text { Ascorbic acid } \\
\text { deficiency }\end{array}$ & 45 & $162(71.1)$ & 45 & $190(69.1)$ & 0.633 \\
\hline $\begin{array}{l}\text { Vitamin B12 } \\
\text { deficiency }\end{array}$ & 2.4 & 198(86.8) & 2.4 & $237(86.2)$ & 0.829 \\
\hline
\end{tabular}

Recommended Dietary Allowance (RDA), the daily dietary intake level of a nutrient considered sufficient by the Food and Nutrition Board of the Institute of Medicine to meet the requirements of $97.5 \%$ of healthy individuals in each life-stage and sex group. The definition implies that the intake level would cause a harmful nutrient deficiency in just $2.5 \%$.

\section{PREVALENCE OF MICRONUTRIENT DEFICIENT DIET AMONG UNDERGRADUATES IN LAGOS}

Almost all the under-graduates had vitamin B12 (86.8\% M, $86.2 \% \mathrm{~F})$, pyridoxine $(92.5 \% \mathrm{M}, 90.2 \% \mathrm{~F})$ calcium $(98.7 \% \mathrm{M}$, 99.6\% F) and potassium (100\% M, 99.6\% F) deficient diet while almost half of them consumed excess sodium. Most of the females $(58.9 \%)$ had iron deficient diet while more than half $(56.1 \%)$ of the males consumed zinc deficient diet (Table 4).

\section{PREDICTORS OF OBESITY}

Males were 0.597 times more likely to develop obesity than females and students who had inconsistent amount of income were 2.23 times more likely to develop obesity than those who had no source of income. Moreover, for every one unit increase in folate, the likelihood of developing obesity was 1.0 .

\section{DISCUSSION}

The average age was $20.31 \pm 3.454$ with $54.7 \%$ being females and $45.3 \%$ being males. Most of the students had educated mothers and enlightened parents who lived in detached houses/duplex (23\%) or bungalows (28\%) or self-contained apartments within story buildings (41.6\%) but many (37.6\%) of the students received less than N10, 000 (USD 30) monthly pocket money or had no consistent source of income.

Most of the nutrients and energy were deficient except carbohydrates. This study contradicts the study by Hirshberg where intakes of total energy surpassed guidelines ${ }^{26}$ but agrees with another study in Ghana where female respondents met 97 percent of energy requirement while the males met only 66 percent. ${ }^{27}$ The energy might have been deficient because many undergraduate students in Nigeria eat only two times daily and buy most of their meals from fast food restaurants. ${ }^{11}$ Since many undergraduates perceive inadequate funds as a reason for not eating healthy, they might have purchased small portion sizes of meals that were affordable rather than purchasing enough portion size to meet their needs. ${ }^{11}$ The low energy and high carbohydrate intake infer that the students' diet consisted of majorly simple carbohydrates with little energy from other sources such as protein and fat rich foods. Energy is very critical in metabolism because the transport, synthesis, and breakdown of nutrients and molecules in a cell require the use of energy. ${ }^{28}$ Adequate energy intake is also important to reserve protein for more important functions like hormone and enzyme production and building of tissues rather than energy generation. Protein intake was better than energy especially among the females probably because many of them ate meat which contains a high amount of qualitative protein daily; however, some of it could have been converted to energy rather than fulfilling the special functions of protein.

The fiber intake was not adequate. This agrees with the result of another study by Irazusta which shows only $43 \%$ of females and $51 \%$ of males met the recommendations for fiber intake. ${ }^{29}$ Adequate fiber is very important in bowel movement, weight control and prevention of NCDs generally. ${ }^{30}$

Iron intake was not adequate for all the age groups especially among females. Majority (92\%) of the females had iron deficiency. They met only $40 \%$ of their requirement while the males met $78 \%$ of their Recommended Dietary Allowance (RDA). Females require more iron than males in order to replace menstrual iron losses which make them vulnerable to anemia and other iron deficiency disorders. Iron deficiency anaemia should be avoided among females of reproductive age because children born to such people are 
Table 5: Predictors of Obesity

\begin{tabular}{|c|c|c|c|}
\hline Variables & Odds Ratio & 95\% Confidence Interval & $P$-value \\
\hline Age & 1.01 & $0.949-1.081$ & 0.699 \\
\hline Sex & 0.6 & $0.370-0.963$ & $0.034^{*}$ \\
\hline \multicolumn{4}{|l|}{ Level of education } \\
\hline \multicolumn{4}{|l|}{ No education } \\
\hline Some primary & 0 & 0 & 0.999 \\
\hline Primary & 0.75 & $0.113-4.974$ & 0.765 \\
\hline Some secondary & 1.91 & $0.271-13.458$ & 0.516 \\
\hline Secondary & 0.51 & $0.067-3.913$ & 0.518 \\
\hline Some tertiary & 0.99 & $0.230-4.267$ & 0.99 \\
\hline Tertiary & 1 & $0.221-4.549$ & 0.998 \\
\hline Quoranic/vocational & 0.88 & $0.218-3.532$ & 0.854 \\
\hline Other forms of education & 0.57 & $0.044-7.567$ & 0.673 \\
\hline \multicolumn{4}{|c|}{ Occupation of heads of household } \\
\hline \multicolumn{4}{|l|}{ Farming } \\
\hline Petty trading & 0 & 0 & 0.999 \\
\hline Civil servant & 2.58 & $0.623-10.675$ & 0.191 \\
\hline Business & 0.75 & $0.409-1.393$ & 0.369 \\
\hline Highly skilled professional & 1.09 & $0.621-1.913$ & 0.764 \\
\hline \multicolumn{4}{|l|}{ Average Income per month } \\
\hline \multicolumn{4}{|l|}{ No income } \\
\hline \#1000-5000 & 0.54 & $0.100-2.923$ & 0.475 \\
\hline \#5001- $\$ 10,000$ & 0.57 & $0.182-1.754$ & 0.323 \\
\hline$\# 10,001-\# 20,000$ & 1.18 & $0.520-2.671$ & 0.695 \\
\hline Above 20,000 & 1.23 & $0.592-2.558$ & 0.577 \\
\hline Not consistent & 2.23 & $1.034-4.789$ & $0.041^{*}$ \\
\hline \multicolumn{4}{|l|}{ Micronutrients } \\
\hline Calcium & 1 & $0.999-1.001$ & 0.655 \\
\hline Iron & 1 & $0.960-1.031$ & 0.791 \\
\hline Zinc & 0.99 & $0.927-1.058$ & 0.772 \\
\hline Folate & 1 & $1.000-1.004$ & $0.038^{*}$ \\
\hline Potassium & 1 & $1.000-1.001$ & 0.428 \\
\hline Sodium & 1 & $1.000-1.000$ & 0.498 \\
\hline Vit. B6 & 0.4 & $0.148-1.063$ & 0.066 \\
\hline Vit. C & 1 & $0.998-1.006$ & 0.379 \\
\hline Vit. B12 & 0.99 & $0.918-1.075$ & 0.868 \\
\hline
\end{tabular}

likely to suffer poor growth and cognition. This result is similar to the one obtained in the Ghana study above where intake of iron was low among the females. ${ }^{31}$

Zinc intake was adequate among females but not adequate for males who require more zinc. Almost half (49\%) of the males had zinc deficiency. Its adequacy is critical to the males' reproductive ability. Zinc enables the male body to produce testosterone apart from other general functions such as production of enzymes and promoting immune function. ${ }^{32}$ Calcium intake was low compared to RDA (less than $50 \%$ ). This is probably because the undergraduate population did not consume enough milk or milk products daily despite its importance as a major source of dietary calci- um. ${ }^{33}$ The proportion of students who took milk and its products in other studies in similar population was low. 8,34

Sodium intake was in excess for both males and females while potassium deficiency was almost universal. Almost all the under-graduates (99\%) had potassium deficiency while less than half had hypernatremia This is probably a result of frequent consumption of processed foods and fast food restaurants while consuming inadequate fruits and vegetables. Diets based on processed foods are high in sodium and low in potassium. ${ }^{25}$ This finding agrees with the study by Burke et al among undergraduates in University of New Hampshire in United States which discovered that more than $90 \%$ of college students exceeded sodium recommen- 
dations. ${ }^{35}$ High level of sodium and low level of potassium intake are risk factors for hypertension in many people and it is recommended that sodium intake should be limited while potassium should be increased. ${ }^{36}$ Research has shown that the problem with hypertension is not just high level of sodium but the balance between sodium and potassium. Higher potassium intake has been found to result in blood pressure lowering in the overall population with more pronounced effects in patients with hypertension or consuming a high sodium diet. ${ }^{31}$ Unfortunately, less than one third of Nigerians consume adequate amount of fruits and vegetables which are rich in Potassium.

This result is similar to another one in Ghana, where about two-thirds had normal BMIs and a third were either overweight, obese or underweight. ${ }^{31}$ The prevalence of general overweight \& obesity in this study was lower than obtained among undergraduates in South Western Nigeria generally $(29 \%, 6 \%)$ and in a Central University in the West Bank (25\%, 7.2\%). .37 The prevalence of abdominal obesity was significantly higher among females compared to males using waist circumference and waist to hip ratio $(\mathrm{p}=0.000)$. The percentage body fat assessed using bio-electrical impedance analysis yielded the highest rate of obesity which was higher among males though the difference was not statistically significant.

\section{LIMITATIONS}

Ideally, it would have been better to obtain and use blood samples to demonstrate objectively the measure of deficiency or excess of micronutrients; however, 24-hour diet recall was used as a proximate. There could have been a challenge with accuracy of recall and extrapolating micronutrient deficiency from two days nutrient intake could have yielded some degree of inaccuracy.

\section{CONCLUSIONS}

Mean nutrient intake was lower than RDA for most micronutrients except thiamine and sodium ,which were too high. Micronutrient-related malnutrition and central obesity were higher than reported in previous studies. Male gender, inconsistent income and increased amount of folate were significant predictors of obesity. Nutrition and lifestyle education programs targeting behavioral change should be instituted in universities through the school curriculum. Whole foods such as legumes, milk, fruits and vegetables which can also supply iron, calcium, potassium, folate and other micronutrients and control weight gain are recommended for the undergraduates.

\section{ACKNOWLEDGEMENTS}

The authors wish to acknowledge the Deans of Students affairs of the three universities for granting permission to collect data.

\section{ETHICS APPROVAL AND CONSENT TO PARTICIPATE}

The study was conducted according to the guidelines laid down in the Declaration of Helsinki. Ethical approval was obtained from the Health Research and Ethics Committee of the Lagos University Teaching Hospital (Ref No: ADM/ DCST/HREC/APP/179 and Lagos State University Teaching Hospital (Ref No: LREC/10/06/630). Informed written consent was obtained from all students as well as parental consent from those who were younger than eighteen (18) years of age before conducting the study, and confidentiality was maintained.

\section{AVAILABILITY OF DATA AND MATERIAL}

The datasets used and analyzed during the current study are available from the corresponding author on reasonable request.

\section{FUNDING}

None

\section{AUTHORSHIP CONTRIBUTIONS:}

FO, SA, EA, OO conceptualized and designed the study. F.O acquired and interpreted the data. FO, SA, EA and KN drafted the manuscript and critically revised it for important intellectual content. KN was a major contributor in writing the manuscript. All authors read and approved the final manuscript.

\section{COMPETING INTERESTS}

The authors completed the Unified Competing Interest form at www.icmje.org/coi disclosure.pdf (available upon request from the corresponding author), and declare no conflicts of interest.

\section{CORRESPONDENCE TO:}

\section{Dr. Foluke A. Olatona}

Department of Community Health and Primary Care

College of Medicine, University of Lagos, Nigeria

Submitted: March 09, 2020 GMT, Accepted: October 10, 2020

GMT

This is an open-access article distributed under the terms of the Creative Commons Attribution 4.0 International License (CCBY-4.0). View this license's legal deed at http://creativecommons.org/licenses/by/4.0 and legal code at http://creativecommons.org/licenses/by/4.0/legalcode for more information. 


\section{REFERENCES}

1. Tulchinsky TH. Micronutrient deficiency conditions: Global health issues. Public Health Rev. 2010;32(1):243-255. doi:10.1007/bf03391600

2. Otemuyiwa IO, Adewusi SRA. Food Choice and Meal Consumption Pattern Among Undergraduate Students In Two Universities In Southwestern Nigeria. Journal of Nutrition Health. 2012;21(4):233-245. doi:10.1177/0260106013510994

3. World Health Organization. Diet and Physical Activities. Prevention of Diseases; 2011.

4. Abdulkarim AA, Otuneye AT, Ahmed P, Shattima DR. Adolescent malnutrition: Prevalence and pattern in Abuja Municipal Area Council, Nigeria. Nig J Paed. 2014;41(2):99-103. doi:10.4314/njp.v41i2.4

5. World Health Organization. Physical Status: The Use and Interpretation of Anthropometry. Geneva, Switzerland: World Health Organization; 1995:854.

6. World Health Organization. WHO Global Strategy on Diet, Physical Activity and Health. 2014.

7. World Health Organization. Physical Status: The use and interpretation of anthropometry: Report of A WHO Expert Committee:2008. WHO technical series 859.

8. Ono T, Guthold R, Strong K. WHO Global Comparable Estimates: Global Infobase data for saving lives. 2005. https://apps.who.int/infobase/Inde x.aspx.

9. World Health Organization. World Health Report, 2000. Geneva: World Health Organization; 2000.

10. Dairo MD, Ige OK. Supplementation of micronutrient in community micronutrient deficiency prevention programmes. Annals of Ibadan Postgraduate Medicine. 2009;7(1):6-9.

11. Olatona FA, Onabanjo OO, Ugbaja RN, Nnoaham KE, Adelekan DA. Dietary habits and metabolic risk factors for non-communicable diseases in a university undergraduate population. J Health Popul Nutr. 2018;37(1):21. doi:10.1186/s41043-018-0152-2

12. Bray GA. Complications of obesity. Ann Intern Med. 1985;103(6 Pt 2):1052-1062. doi:10.7326/0003-4 819-103-6-1052
13. Flegal KM, Kit BK, Orpana H, Graubard BI. Association of all-cause mortality with overweight and obesity using standard body mass index categories: A systematic review and meta-analysis. JAMA. 2013;309(1):71-82. doi:10.1001/jama.2012.113 $\underline{905}$

14. Must A, McKeown NM, Groot LJ, Beck-Peccoz P, Chrousos G, Dungan K, et al. The Disease Burden Associated with Overweight and Obesity. Endotext. South Dartmouth, MA: MDText.com, Inc.;2000-2012

15. Whitlock G, Lewington S, Sherliker P, Clarke R, Emberson J. Body-mass index and cause-specific mortality in 900000 adults: Collaborative analyses of 57 prospective studies. Lancet. 2009;373(9669):1083-1096. doi:10.1016/s0140-6736(0 9)60318-4

16. Wilson PWF, D'Agostino RB, Sullivan L, Parise H, Kannel WB. Overweight and obesity as determinants of cardiovascular risk: The Framingham experience. Arch Intern Med. 2002;162(16):1867-1872. doi:10.100 1/archinte.162.16.1867

17. Allen L, de Benoist B, Dary O, Hurrell R. Guidelines on Food Fortification with Micronutrients. World Health Organization and Food and Agricultural Organization of the United Nations. Geneva: World Health Organization; 2006.

18. Fairfield KM, Fletcher RH. Vitamins for chronic disease prevention in adults: Scientific review. JAMA. 2002;287(23):3116-3126. doi:10.1001/jama.287.23.31 $\underline{16}$

19. Crombie AP, Ilich JZ, Dutton GR, Panton LB, Abood DA. The Freshman Weight Gain Phenomenon Revisited. Nutrition Review. 2009;67(2):83-94. doi:1 0.1111/j.1753-4887.2008.00143.x

20. Arnett JJ. Emerging adulthood: A theory of development from the late teens through the twenties. TheAmerican Journal of Psychiatry. 2000;55(5):469-480. doi:10.1037/0003-066x.55.5.469

21. Deforche B, Dyck DV, Deliens T, Bourdeaudhuij ID. Changes In Weight, Physical Activity, Sedentary Behaviour And Dietary Intake During The Transition To Higher Education: A Prospective Study. Int J Behav Nutr Phys Act. 2015;12(1):16. doi:10.1186/s12966-01 5-0173-9 
22. Mokdad AH, Ford ES, Bowman BA, Dietz WH, Vinicor F, Bales VS, et al. Prevalence of Obesity, Diabetes, And Obesity-Related Health Risk Factors. Journal of the American Medical Association. 2003;289:76-79.

23. Onyechi UA, Okolo AC. Prevalence of Obesity Among Undergraduate Students, Living In Halls Of Residence, University Of Nigeria, Nsukka Campus, Enugu State. Anim Res Int. 2008;5(3):928-931 928. do i:10.4314/ari.v5i3.48764

24. Adu OB, Falade AM, Nwalutu EJ, Elemo BO, Magbagbeola OA. Nutritional Status of Undergraduates In A Nigerian University In SouthWest Nigeria. International Journal of Medicine and Medical Sciences. 2009;(8):318-324.

25. Kaplan NM. Primary Hypertension: Pathogenesis. In: Kaplan NM, ed. Kaplan's Clinical Hypertension. 9th ed. Philadelphia: Lippincott Williams \& Wilkins; 2006:50-121.

26. Hirshberg SE, Fernandes J, Melanson KJ, Dwiggins JL, Dimond ES, Lofgren IE. Dietary Sugars Predict Chronic Disease Risk Factors In College Students. Topics in Clinical Nutrition. 2011;26(4):324-334. do $\mathrm{i}: 10.1097 / \mathrm{tin} .0 \mathrm{~b} 013 \mathrm{e} 318237 \mathrm{~d} 026$

27. Nti CA, Pecku E, Opare-Obisaw C. Nutrition knowledge, meal patterns and nutritional status of energy drink users in a Ghanaian University. Journal of Human Ecology. 2015;49(1-2):1-7. doi:10.1080/097 $\underline{09274.2015 .11906818}$

28. Boundless. The Role of Energy and Metabolism.” Boundless Biology Boundless, 26 May. https://www.b oundless.com/biology/textbooks/boundless-biology.T extbook/metabolism-6/energy-and-metabolism-68/th e-role-of-energy-and-metabolism-2016;341-11478/m etabolism-341-11478/. Accessed February 1, 2017.

29. Irazusta A, Hoyos I, Irazusta J, Ruiz F, Díaz E, Gil J. Increased cardiovascular risk associated with poor nutritional habits in first-year university students. Nutrition Research. 2007;27(7):387-394. doi:10.1016/ j.nutres.2007.05.007
30. Anderson JW, Baird P, Davis RH, et al. Health Benefits of Dietary Fiber. Nutrition Reviews. 2009;67(4):188-205. doi:10.1111/j.1753-4887.2009.00 189.x

31. Aburto NJ, Hanson S, Gutierrez H, Hooper L, Elliott P, Cappuccio FP. Effect of increased potassium intake on cardiovascular risk factors and disease: Systematic review and meta-analyses. BMJ. 2013;346(apr03 3):f1378-f1378. doi:10.1136/bmj.f137 $\underline{8}$

32. Frederickson CJ, Koh J-Y, Bush AI. The Neurobiology of Zinc in Health and Disease. Nat Rev Neurosci. 2005;6(6):449-462. doi:10.1038/nrn1671

33. Olatona FA, Sosanya A, Sholeye OO, Obrutu OE, Nnoaham KE. Knowledge of fruits and vegetables, consumption pattern and associated factors among adults in Lagos State, Nigeria. Research Journal of Health Sciences. 2018;6(2):50. doi:10.4314/rejhs.v6i $\underline{2.2}$

34. Mohammad A, Neda A, Mohsen E, Kazem R. Nutrition Knowledge, The Attitude and Practices of College Students. Facta Universitatis Series: Physical Education and Sport. 2011;9(3):349-357.

35. Burke JD, Reilly RA, Morrell JS, Lofgren IE. The University of New Hampshire's Young Adult Health Risk Screening Initiative. Journal of American Dietetics Association. 2009;109(10):1751-1758. doi:1 $\underline{0.1016 / j . j a d a .2009 .07 .005}$

36. Adrogué HJ, Madias NE. Sodium and Potassium in the Pathogenesis of Hypertension. $N$ Engl J Med. 2007;356(19):1966-1978. doi:10.1056/nejmra064486

37. Yasin IT, Nagham AY, Wiam TK, Lama O, Abu R, Ahmad BR, et al. Prevalence and Risk Factors of Obesity and Hypertension Among Students at A Central University in The West Bank. Libyan Journal of Medicine. 2012;7:10. doi:10.3402/lim.v7i0.19222 